\title{
Carbon footprint of university food courts and its relationship with type of food consumed
}

\section{Huella de carbono de las cafeterías universitarias y su relación con el tipo de alimento consumido}

\author{
ALANIS, Claudia $\uparrow^{1} \dagger^{*}$, ÁVILA-CORDOBA, Liliana ${ }^{2}$, ÁLVAREZ-ARTEAGA, Gustavo ${ }^{3}$ and \\ NATIVIDAD, Reyna ${ }^{1}$ \\ ${ }^{1}$ Chemical Engineering Lab., Centro Conjunto de Investigación en Química Sustentable, UAEM-UNAM, Universidad \\ Autónoma del Estado de México, Km 14.5 Toluca-Atlacomulco road, Toluca, México, 50200. \\ ${ }^{2}$ Engineering Faculty, Universidad Autónoma del Estado de México, Cerro de Coatepec S/N, Ciudad Universitaria, Toluca, \\ México 50110. \\ ${ }^{3}$ Urban and Regional Planning Faculty, Universidad Autónoma del Estado de México, Mariano Matamoros, esquina Av. \\ Paseo Tollocan, Toluca, México, 50130.
}

ID $1^{\text {st }}$ Author: Claudia, Alanis / ORC ID: 0000-0001-6935-1798, CVU CONACYT ID: 360631

ID $1^{\text {st }}$ Co-author: Liliana, Ávila-Cordoba / ORC ID: 0000-0002-1073-5196, CVU CONACYT ID: 323060

ID $2^{\text {nd }}$ Co-author: Gustavo, Álvarez-Arteaga / ORC ID: 0000-0002-0260-3484, CVU CONACYT ID: 100403

ID $3^{\text {rd }}$ Co-author: Reyna, Natividad / ORC ID: 0000-0001-8978-1066, CVU CONACYT ID: 87755

DOI: $10.35429 / J U M .2021 .14 .5 .22 .28$

Received July 12, 2021; Accepted December 30, 2021

\begin{abstract}
The aim of this work was to establish the environmental carbon footprint impact of food courts of the Autonomous University of the State of Mexico by type of food consumed. This was achieved by conducting a life cycle assessment according to ISO 14044, 2006. The environmental impact was calculated with the SimaPro 9.1.0.11 PhD software with the EU \& DK input/output food database. The method was IPCC 2013. The assessed impact category was global warming potential 100 years, associated with the type of food consumed, classified in the following groups: sugar, fruit and vegetables, dairy, grain crops, oils and fats, meat and fish products. It was found that the carbon footprint of the food courts is $7199.29 \mathrm{kgCO}_{2} \mathrm{eq} / \mathrm{day}$, with a diet constituted by $42 \%$ fruits and vegetables, $19 \%$ meat and fish products, $12 \%$ grain crops, $11 \%$ dairy and $8 \%$ sugar, oils and fats. The average of carbon footprint per student per day according to the food consumed in University food courts is 3.33 $\mathrm{kgCO}_{2}$ eq.
\end{abstract}

Life cycle assessment, Sustainable diet and nutrition education

\begin{abstract}
Resumen
El objetivo de este trabajo fue evaluar la huella de carbono que tienen las cafeterías universitarias de la Universidad Autónoma del Estado de México, por tipo de alimento consumido. La metodología se desarrolló mediante el análisis de ciclo de vida bajo la norma ISO 14044, 2006. La evaluación del impacto ambiental se calculó con el software de PhD SimaPro 9.1.0.11 con la base de datos de alimentos EU \& DK entrada/salida. El método fue el del IPCC, 2013. La categoría de impacto evaluada fue el potencial de calentamiento global a 100 años, asociada al tipo de alimentos consumido, los cuales se clasificaron en los siguientes grupos: azúcar, frutas y verduras, lácteos, cereales, aceites y grasas, y productos de carne y pescado. Se encontró que la huella de carbono de las cafeterías universitarias es de $7199.29 \mathrm{kgCO}_{2} \mathrm{eq} / \mathrm{día}$, con una dieta constituida por un $42 \%$ frutas y verduras, $19 \%$ productos de carne y pescado, $12 \%$ cereales, $11 \%$ lácteos y $8 \%$ azúcar, aceites y grasas. El promedio de huella de carbono al día por estudiante según el alimento consumido en las cafeterías universitarias es de 3.33 $\mathrm{kgCO}_{2} \mathrm{eq}$.
\end{abstract}

Análisis de ciclo de vida, Dieta sustentable, y educación nutricional

Citation: ALANIS, Claudia, ÁVILA-CORDOBA, Liliana, ÁLVAREZ-ARTEAGA, Gustavo and NATIVIDAD, Reyna. Carbon footprint of university food courts and its relationship with type of food consumed. Journal University Management. 2021. 5-14: 22-28

\footnotetext{
* Author Correspondence (e-mail: claudia.alanis.iq@gmail.com)

$\dagger$ Researcher contributing as first author.
} 


\section{Introduction}

The global food systems emit 20-35 \% of greenhouse gases (GHG) emissions, and it is necessary to achieve critical progress on all 17 Sustainable Development Goals (SDGs) (FAO, 2019). One-third of food produced for human consumption is lost or wasted globally, which amounts to about 1.3 billion (FAO, 2011). The sustainable consumption of diet with low environmental impacts contribute to food and nutrition security to a healthy life for present and future generations, adopting a sustainable production and consumption throughout the global food supply chain (Ribal et al., 2016). Sustainable diets are protective and respectful of biodiversity and ecosystems, culturally acceptable, accessible, economically fair and affordable; nutritionally adequate, safe and healthy; while optimizing natural and human resources (FAO, 2011) The sustainable consumption, respond to basic needs and bring a better quality of life, while minimizing the use of natural resources, toxic materials and emissions of waste and pollutants over the life cycle, so as not to jeopardize the needs of future generations (UNEP, 2007).

The Intergovernmental Panel on Climate Change (IPCC) in their most recent report recognized that "Consumption of healthy and sustainable diets" presents major opportunities for reducing GHG emissions from food systems and improving health outcomes, support the preservation of biodiversity and planetary health. (IPCC, 2019). The nutrition diet and school education converge with consumption habits and reduce GHG while remaining nutritionally adequate (Colombo et al., 2020).

Climate change is an aspect to build a sustainable healthy lunch in the University Food Courts (UFC) (Ribal et al., 2016). The source of emissions in UFC spaces are derived from quality of nutrition (meals), food waste and the management options in the waste hierarchy. Incorporate these topics associated with circularity and the integral management of waste in environmental high education programs has been achieved under a life cycle perspective.

Life cycle assessment (LCA) for the calculation of environmental impacts such as carbon footprint, is an internationally technique that analyses a product over its entire life cycle, quantifying its environmental impact.
Herrero et al., (2020) studied an integration of life cycle methods, including the role of embedded impacts within environmental, cost and nutritional attributes.

The sustainability with life cycle perspective in UFC allows to formulate institutional public, suggesting plausible sustainable solutions, positioning universities in a global interest of scientific community (Kooduvalli et al., 2020; Rada et al., 2020), considering environmental aspects implementing eating habits, including high amounts of plant-based food (e.g., vegetables, fruits, seeds, nuts, legumes, and whole grain foods) and moderate amounts of animal-based foods (e.g., meat, poultry, seafood, eggs, and dairy) (Steenson \& Buttriss, 2020). Also, a sustainable solution is the reduction in the consumption of high environmental impact food, a minimum of food waste generation and choosing unpacked foods or with a minimum of package, among others.

The objective of this study was to assess the environmental carbon footprint (CFP) impact of food courts of Autonomous University of the State of Mexico (UAEMex) by type of food consumed. In part 2, the methodology describes the sector of society for data collection, which allowed the integration of an inventory for LCA from the food system of UFC. The results are reported in part 3 , the evaluation was of the mid-point environmental impact of global warming potential. This research pretends to establish a representative baseline of current diets in UFC with a potential positive impact on healthy diets and on the reduction of environment impacts such as carbon footprint.

\section{Methodology}

The methodology was implemented in the municipality of Toluca, State of Mexico; data on food consumption was collected per day considering 27 UFC, which were classified into four sections (S1, S2, S3 and S4), making an allowance for routes of waste collection by the Department of Services of the UAEMex (Table $1)$. 


\begin{tabular}{|c|c|}
\hline Sections & Academic spaces \\
\hline S1 & $\begin{array}{l}\text { Faculty of Medicine } \\
\text { Faculty of Urban and Regional Planning } \\
\text { Faculty of Nursing } \\
\text { Faculty of Chemistry } \\
\text { Faculty of Anthropology } \\
\text { Faculty of Languages } \\
\text { Faculty of Dentistry }\end{array}$ \\
\hline S2 & $\begin{array}{l}\text { San Cayetano } \\
\text { Faculty of Gastronomy and Tourism } \\
\text { Administrative building } \\
\text { Faculty of Agricultural Sciences } \\
\text { Cerrillo piedras blancas } \\
\text { El Rosedal }\end{array}$ \\
\hline S3 & $\begin{array}{l}\text { International Centre for Language and } \\
\text { Culture (CILC) } \\
\text { Faculty of Tourism and Gastronomy } \\
\text { University Town } \\
\text { Faculty of Performing Arts } \\
\text { Faculty of Economics } \\
\text { Faculty of Geography } \\
\text { Faculty of Engineering }\end{array}$ \\
\hline S4 & $\begin{array}{l}\text { Campus No. 2, Preparatory School } \\
\text { "Nezahualcóyotl" } \\
\text { Faculty of Accounting and Administration } \\
\text { UAEM "Unidad Los Uribe" Santa Cruz } \\
\text { Atzcapotzaltongo } \\
\text { Central Library } \\
\text { Faculty of Psychology } \\
\text { Preparatory } 3 \text { "Cuauhtémoc" } \\
\text { Center of Sustainable Chemistry UNAM- } \\
\text { UAEM } \\
\text { Campus No. 4, Preparatory School "Lic. } \\
\text { Ignacio Ramírez Calzada" } \\
\text { Campus No. 1, "Lic. Adolfo López Mateos" } \\
\text { Campus No. 5, Preparatory School "Dr. } \\
\text { Angel Ma. Garibay Kintana " }\end{array}$ \\
\hline
\end{tabular}

Table 1 Academic spaces with University food courts in the UAEMex

Source: Department of services of the UAEMex, 2020

The data collection was carried out by means of a survey that was answered by the UFC managers as well with information by space, management capacity from the institution, mobile infrastructure and management options with a scientific approach that is developed within the same University spaces.

The LCA was developed under Life Cycle Assessment, Requirements and Guidelines (ISO 14044, 2006) and (UNEP, 2003). The evaluation of the environmental impact was calculated with the SimaPro 9.1.0.11 PhD (PRé Sustainability, 2021) software with the EU \& DK input/output food database. The method was IPCC 2013.
The assessed impact category was global warming potential 100 years, associated with the type of food consumed, classified in the following groups: sugar, fruit and vegetables, dairy, grain crops, oils and fats, meat and fish products (Figure 1).

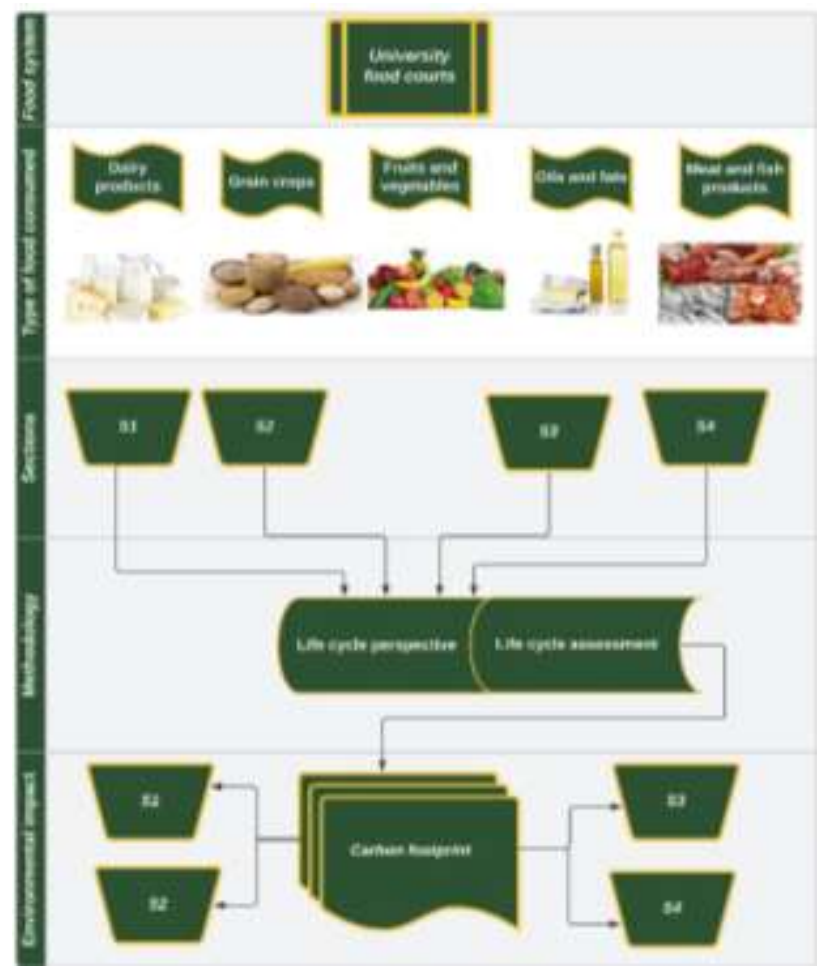

Figure 1 Food system of University food courts of the UAEMex with life cycle perspective.

Source: Own Authorship

Diagramming software: Ludichart Web 2.0

\section{Results and discussion}

According to the survey applied to the UFC managers, the type of food that is mainly consumed is fruits and vegetables, $42 \%$; meats and fish products, $19 \%$; grain crops, $12 \%$; dairy products, $11 \%$; and finally, sugar, oils and fats, $8 \%$. These results are depicted in Graphic 1. It can be observed in Graphic 2 that the sources of GHG emissions, animal-based food (meat, fish and dairy products), considerably contribute to carbon dioxide equivalents $\left(\mathrm{kg} \mathrm{CO}_{2} \mathrm{eq}\right)$ towards climate change, more than plant-based foods, this is in concordance with that previously reported by Bastian et al., (2021). In United States schools canteens, it has been reported that the highest environmental contribution occurred at the food procurement stage $(85 \%)$, while the lowest occurred at food preparation (2\%) (Herrero et al., 2020). 


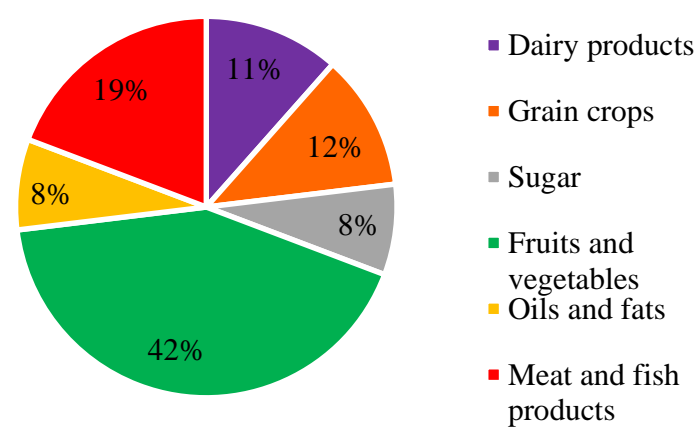

Graphic 1 Percentage of consumption by type of food in University food courts of the UAEMex

Source: Own Authorship

The major long-lived greenhouse gases in the atmosphere are carbon dioxide $\left(\mathrm{CO}_{2}\right)$, methane $\left(\mathrm{CH}_{4}\right)$ and nitrous oxide $\left(\mathrm{N}_{2} \mathrm{O}\right)$. In order to integrate the effect of the three gases on the global warming, the unit of $\mathrm{kgCO}_{2}$ eq was established. In such a unit, it is considered that one ton of $\mathrm{CH}_{4}$ will cause the same amount of warming as 28-36 tons of $\mathrm{CO}_{2}$, in a similar way, 1 tonne of $\mathrm{N}_{2} \mathrm{O}$ is considered to cause the same warming than 265-298 tons of $\mathrm{CO}_{2}$ (US EPA, 2021). The CFP by type of food consumption in all sections of the UAEMex, is depicted in graphic 2. It is interesting to observe that despite not being the most consumed food (see Graphic 1), meat and fish products have the highest environmental contribution $34-47 \%$ emitting (71.34-1275.84 $\left.\mathrm{kgCO}_{2} \mathrm{eq}\right)$.

This is because the animal-based food production requires a high amount of water and volume of crops. Mekonnen \& Hoekstra (2012) reported that one kilocalorie of beef is estimated to have been produced with 20 times more water than one kilocalorie of a grain food or starchy root vegetable. This also explains why the consumption of dairy products represents the second largest contributor to the CFP in the UFC. It can be observed in Graphic 2 that this type of food contributes with $29-44 \%$ (91.59$1201.37 \mathrm{kgCO}_{2} \mathrm{eq}$ ) to the CFP.

Fruits and vegetables are the type of food mostly consumed (see Graphic 1), nevertheless, it only contributes with $31.03-432.65 \mathrm{kgCO}_{2} \mathrm{eq}$ that represents $13-15 \%$ of the total CFP of the UFC. The contribution of the other type of foods is as follows, sugar (3-4\%) 8.85-124.01 $\mathrm{kgCO}_{2}$ eq, oils and fats (2-5\%) 5.23-171.05 $\mathrm{kgCO}_{2} \mathrm{eq}$, and grain crops (1\%) 2.18-27.08 $\mathrm{kgCO}_{2}$ eq.
These results suggest that a diet with an increased ratio of (fruits+ vegetables+ grain crops consumption)/ (meat+fish+dairy products consumption), would reduce the CFP of the UFC at UAEMex. This suggestion is worth to be analysed also in the context of nutrition, however, such an analysis is out of the scope of this work.

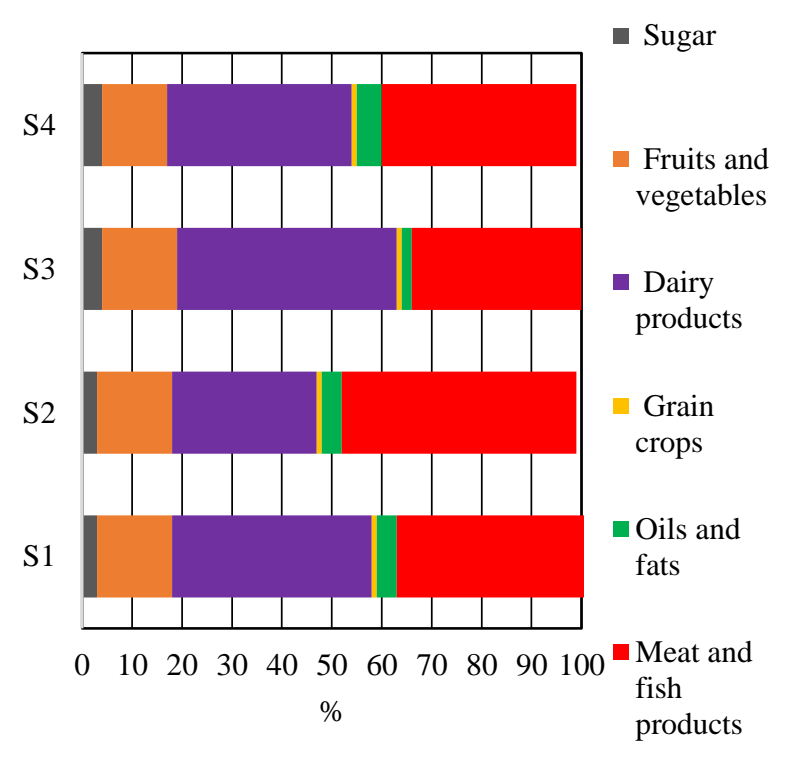

Graphic 2 Percentage of carbon footprint $\left(\mathrm{kgCO}_{2} \mathrm{eq}\right)$ by type of consumed food in sections of the UAEMex using the IPCC 2013 method GWP 100 years V1.03 Source: Own Authorship

Graphic 3 shows the CFP in units of $\mathrm{kgCO}_{2} \mathrm{eq}$ by type of consumed food in the different sections of the UAEMex. According to the results, S4 has the highest CFP, 1275.89 $\mathrm{kgCO}_{2} \mathrm{eq}$, and this can be ascribed to the high consumption of meat, fish products and dairy products.

As can be seen, the consumption of dairy products is responsible for the emissions of $904.65 \mathrm{kgCO}_{2}$ eq by the community in $\mathrm{S} 4 . \mathrm{S} 2$ is the section with the lowest GHG emissions. These important differences can be explained based on the number of academic spaces in S4 (9), which is almost double than the ones in S2 (5). 


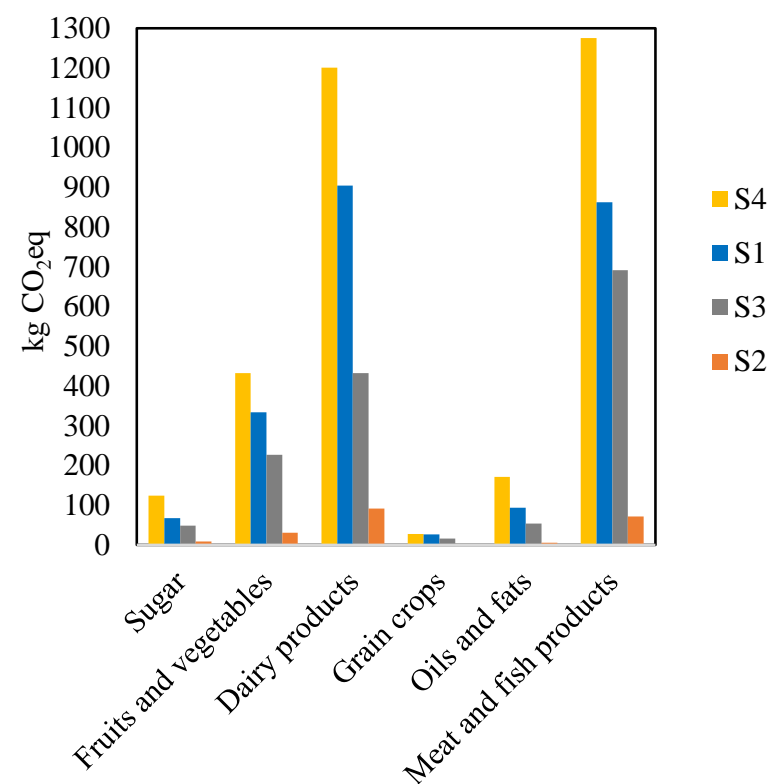

Graphic 3 Carbon footprint $\left(\mathrm{kgCO}_{2} \mathrm{eq}\right)$ by type of consumed foot in the different sections of the UAEMex using the IPCC 2013 method GWP 100 years V1.03 Source: Own Authorship

It can be observed in Graphic 4 that the contribution order to $\mathrm{N}_{2} \mathrm{O}, \mathrm{CH}_{4}, \mathrm{CO}_{2}$ emissions is $\mathrm{S} 4>\mathrm{S} 1>\mathrm{S} 3>\mathrm{S} 2$. It is not a coincidence that this sequence follows the same order in number of academic spaces per section. This explains why S4, with nine studied UFC, represents the largest environmental contribution with $45 \%$ to the total of GHG emissions $\left(\mathrm{CH}_{4}, \mathrm{CO}_{2}\right.$, and $\left.\mathrm{N}_{2} \mathrm{O}\right)$. Nevertheless, in all cases and at any extent, the contribution to the GHG can be mainly ascribed to the consumption of meat, fish and dairy products.

This in concordance with that reported by González-García and collaborators (2018), who pointed out that in northern and Western Europe, as well as in the United States, the highest carbon footprints in the world are due to the consumption of dairy products in the daily diets. In addition, the meat and dairy products from ruminants, are associated with $\mathrm{CH}_{4}$ enteric fermentation emission, in which food is fermented and decomposed in the digestive tract by the action of microorganisms with the consequent release of methane into the atmosphere (Garcia-Oliveira et al., 2020). Also, the intensively managed grasslands are the dominant source of $\mathrm{N}_{2} \mathrm{O}$ emission in dairy farming systems (Velthof et al., 1998) due to the use of fertilizers. For mitigation strategies, it is important to consider the reduction of these GHG emissions through dietary manipulation.

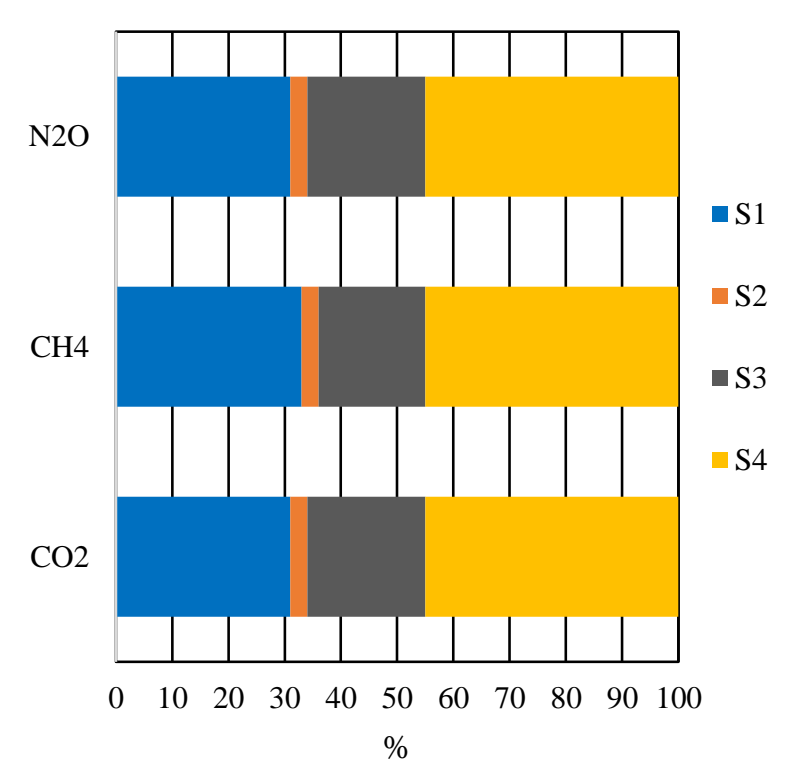

Graphic 4 Percentage of Greenhouse gases (GHG's) contribution in sections of the UAEMex using the IPCC 2013 method GWP 100 years V1.03

Source: Own Authorship

Song et al., (2019) suggest that dietary changes can reduce carbon footprint by $24 \%$ in 2050, however, the differences in age-specific and gender-specific health goals cannot be neglected. The students who were enrolled in Toluca academic spaces of UAEMex at the time of this study, by gender, 22,092 were male and 29,625 women (UAEMex, 2021), the typical age group was 18 to 23 , and the usual number of students attending an UFC fluctuated between 20-80 in a day. Calculating the carbon footprint per student (Table 2), according to the type of food consumed in an UFC is $3.33 \mathrm{kgCO}_{2}$ eq per day. This value coincides with that reported by González-García et al., (2018). These authors reported that the average carbon footprint of adjusted diets to $2000 \mathrm{kcal}$ per day and per person is between $3.33 \pm 1.87 \mathrm{~kg} \mathrm{CO} 2 \mathrm{eq}$, taking into account different diets in global countries with consumption of vegetables, pulses and grain crops, and animal products (mainly animal fat).

\begin{tabular}{|l|l|l|}
\hline Sections & \multicolumn{1}{l}{ kgCO2eq/day } & \multicolumn{1}{c|}{$\%$} \\
\hline S1 & 2288.17 & $32 \%$ \\
\hline S2 & 210.29 & $3 \%$ \\
\hline S3 & 1468.78 & $20 \%$ \\
\hline S4 & 3232.05 & $45 \%$ \\
\hline Total & 7199.28 & $100 \%$ \\
\hline
\end{tabular}

Table 2 Total carbon footprint in spaces of the UAEMex per day and percentage of impact. Source: Own Authorship 
In this context, the World Health Organization (WHO) promotes a healthy diet and protect public health establishing standards to foster healthy dietary practices through ensuring the availability of healthy, nutritious, safe and affordable foods in schools and other public institutions (WHO, 2021). It is important to consider recent public documents which help to promote positive and gentle persuasion to encourage sustainable diets behavior in higher education campuses, like "The Little Book of Green Nudges” (UNEP, 2020), Figure 2.

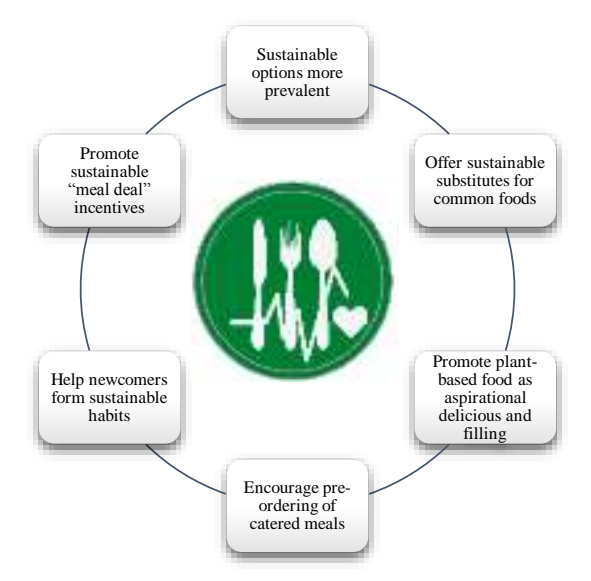

Figure 2 Green nudges for promote a sustainable diet in University food courts

Source: adapted from (UNEP, 2020)

\section{Thanks}

C. Alanis is grateful to the National Council of Science and Technology for the financial support (CVU 360631) to conduct postgraduate studies. Authors are grateful to the Sustainable University Network for the Integral Management of Organic Waste of the Autonomous University of the State of Mexico with registration number 5083/REDP2020 and to UAEMex for financial support through project 6488/2022CIC. The technical support of Citlalit Martínez Soto is also acknowledged.

\section{Conclusions}

The carbon footprint of the food courts of the Autonomous University of the State of Mexico is $7199.29 \mathrm{kgCO}_{2}$ eq/day, with a diet constituted by $42 \%$ fruits and vegetables, $19 \%$ meat and fish products, $12 \%$ grain crops, $11 \%$ dairy and $8 \%$ sugar, oils and fats. The average of carbon footprint per student per day, according to the food consumed in University food courts is 3.33 $\mathrm{kgCO}_{2}$ eq.
This carbon footprint is due to the consumption of meat, fish and dairy products and not to the consumption of fruits and vegetables that is the type of food mostly consumed. For the total University food courts in academic spaces, section "S4" has the $45 \%$ of environmental contribution of total global warming potential, "S1" $32 \%$, "S3" $20 \%$ and "S2", 3\%. Based on our results, it is recommended to promote to increase the consumption of grain crops, fruits and vegetables. This strategy of nutritional education would pursue a behavior change of managers and consumers to choose sustainable healthy diets. Further research could be meals into University food courts, considering nutritional indicators, food waste and cost.

\section{References}

Bastian, G. E., Buro, D., \& Palmer- Keenan, D. M. (2021). Recommendations for Integrating Evidence-Based, Sustainable Diet Information into Nutrition Education.

Colombo, P. E., Patterson, E., Lindroos, A. K., Parlesak, A., \& Elinder, L. S. (2020). Sustainable and acceptable school meals through optimization analysis: an intervention study. Nutrion Journal, 1-15.

FAO. (2011). Global food losses and food waste.

FAO. (2019). Sustainable healthy diets. En Sustainable healthy diets. https://doi.org/10.4060/ca6640en

Garcia-Oliveira, P., Fraga-Corral, M., Pereira, A. G., Prieto, M. A., \& Simal-Gándara, J. (2020). Solutions for the Sustainability of the Food Production and Consumption System. Critical Reviews in Food Science and Nutrition, $O(0)$, $1-17$. https://doi.org/10.1080/10408398.2020.184702 8

González-García, S., Esteve-Llorens, X., Moreira, M. T., \& Feijoo, G. (2018). Carbon footprint and nutritional quality of different human dietary choices. Science of the Total Environment, 644, 77-94. https://doi.org/10.1016/j.scitotenv.2018.06.339 
Herrero, L. G., Costello, C., Menna, F. De, \& Schreiber, L. (2020). Eating away at sustainability. Food consumption and waste patterns in a US school canteen. Journal of Cleaner Production, 123571. https://doi.org/10.1016/j.jclepro.2020.123571 IPCC. (2019). El cambio climático y la tierra.

ISO 14044. (2006). Environmental management - Life cycle assessment - Requirements and guidelines. En International Organization for Standardization.

http://www.springerlink.com/index/10.1007/s1

1367-011-0297-3

Kooduvalli, K., Vaidya, U. K., \& Ozcan, S. (2020). Life Cycle Assessment of Compostable Coffee Pods: A US University Based Case Study. Scientific Reports, 10(1), 1-25. https://doi.org/10.1038/s41598-020-65058-1

Mekonnen, M. M., \& Hoekstra, A. Y. (2012). A Global Assessment of the Water Footprint of Farm Animal Products. Ecosystems. https://doi.org/10.1007/s10021-011-9517-8

PRé Sustainability. (2021). SimaPro.

Rada, E. C., Magaril, E. R., Schiavon, M., Karaeva, A., Chashchin, M., \& Torretta, V. (2020). MSW management in universities: Sharing best practices. Sustainability (Switzerland), 12(12). https://doi.org/10.3390/su12125084

Ribal, J., Fenollosa, M. L., García-Segovia, P., Clemente, G., Escobar, N., \& Sanjuán, N. (2016). Designing healthy, climate friendly and affordable school lunches. International Journal of Life Cycle Assessment, 21(5), 631-645. https://doi.org/10.1007/s11367-015-0905-8

Song, G., Gao, X., Fullana-i-Palmer, P., Lv, D., Zhu, Z., Wang, Y., \& Bayer, L. B. (2019). Shift from feeding to sustainably nourishing urban China: A crossing-disciplinary methodology for global environment-food-health nexus. Science of the Total Environment, 647, 716-724. https://doi.org/10.1016/j.scitotenv.2018.08.040

Steenson, S., \& Buttriss, J. L. (2020). The challenges of defining a healthy and 'sustainable' diet. Nutrition Bulletin, 45(2), 206222.

https://doi.org/https://doi.org/10.1111/nbu.1243 9
UAEMex. (2021). Agenda estadística 2020, Universidad Autónoma del Estado de México.

UNEP. (2003). Evaluation of Environmental Impacts in Life Cycle Assessment. En Meeting report (Vol. 2, Número 1). https://doi.org/10.1186/1758-5996-2-73

UNEP. (2007). Life Cycle Management, A Business Guide to Sustainability (Nordic Ecolabel (ed.); Life Cycle).

UNEP. (2020). The little book of green nunges (UNEP and GRID-Arendal. (ed.)).

US EPA. (2021). Understanding Global Warming Potentials | US EPA. Us Epa. https://www.epa.gov/ghgemissions/understandi ng-global-warming-potentials

Velthof, G. L., Van Beusichem, M. L., \& Oenema, O. (1998). Mitigation of nitrous oxide emission from dairy farming systems. Environmental Pollution, 102(1), 173-178. https://doi.org/10.1016/S0269-7491(98)800304

WHO. (2021). Healthy Diet. Encyclopedia of Gerontology and Population Aging. https://doi.org/10.1007/978-3-319-698922_126-1 